ISSN : $2406-7415$

E-ISSN : $2655-9919$

JURNAL AKUNTANSI DAN BISNIS KRISNADWIPAYANA

DOI: http://dx.doi.org/10.35137/jabk.v8i1.505

Volume 8 Nomor 1 (Januari - April) 2021

\title{
ANALISIS GOOD CORPORATE GOVERNANCE DAN UKURAN PERUSAHAAN TERHADAP KINERJA KEUANGAN PERUSAHAAN PADA PERUSAHAAN KEUANGAN YANG TERDAFTAR DI BURSA EFEK INDONESIA TAHUN 2014 SAMPAI DENGAN TAHUN 2018
}

\author{
Ryan Muhammad Muttawaqil Billah ${ }^{1)}$ \\ Fakultas Ekonomi Universitas Krisnadwipayana \\ Jalan Unkris Jatiwaringin Jakarta Timur \\ Email : muttawaqilryan@gmail.com \\ Diana Gustinya ${ }^{2)}$ \\ Fakultas Ekonomi Universitas Krisnadwipayana \\ Jalan Unkris Jatiwaringin Jakarta Timur \\ Email: dianagustinya@unkris.ac.id
}

\begin{abstract}
This study aims to determine and analyze that managerial ownership, institutional ownership, and company size have an impact on financial performance in financial companies listed on the Indonesia Stock Exchange from 2014 to 2018. The results of the classical assumption test show that the normality test of research is normally distributed. the result of the Asymp value. Sig (2-tailed) of 0.200 so that the value is above the significant level of 0.05 . Multicolonearity test there is no multicolonearity between the independent variables in the regression model, the results of the tolerance calculation for the independent variables are more than 0.10 and the results of the valance inflation factor (VIF) have a VIF value below 10. Heteroscedasticity test: there is no heteroscedasticity. Autocorrelation test: the DW value is 2.018, where the value of $d u$ in the Durbin-Watson table with $n$ showing a sample of 16, and $k$ which shows the number of independent variables of 3 is 0.857 for dL and 1.728 for dU. So that the $D W$ value obtained from the test belongs to the distance $d U<d<4-d U$, with a dU table value of $1.728<2.018$ $<2.272$ indicating that the model used is free from autocorrelation. The $R^{2}$ value of this study is 0.517 , this value means that the total variance of related party transactions around an average of $51.7 \%$ can be explained by the relationship between managerial ownership, institutional ownership, and company size together. While the remaining $48.3 \%$ is influenced by other unexplained factors.
\end{abstract}

Keywords: Financial Performance, Good Corporate Governance, and Company Size

\section{PENDAHULUAN}

Di era digitalisasi ini dan kondisi persaingan perekonomian pada saat pandemi covid 19 saat ini, menentukan keberhasilan peusaha dalam meningkatkan kemakmuran para pemegang saham yang menjadi salah satu faktor penunjang bagi perusahaan dalam meningkatkan kinerja perusahaannya. Kinerja perusahaan yang baik maka dimata para investor akan menjadi pertimbangan penting bagi perusahaan-perusahaan yang termasuk industri manufaktur. Dengan meningkatnya penanaman modal saham yang diberikan oleh investor bagi perusahaan itu tidak hanya bertujuan untuk memperoleh keuntungan, juga dapat mempercepat laju pertumbuhan perusahaan agar dapat bersaing lebih kompetitif baik dalam pasar domistik maupun internasional.Kinerja perusahaan dikatakan baik jika adanya keyakinan para investor terhadap suatu perusahaan bahwa dana yang mereka investasikan dalam kondisi yang aman dan akan memberikan pengembalian 
ISSN : $2406-7415$

E-ISSN : 2655 - 9919

JURNAL AKUNTANSI DAN BISNIS KRISNADWIPAYANA

DOI: http://dx.doi.org/10.35137/jabk.v8i1.505

Volume 8 Nomor 1 (Januari - April) 2021

atas dana yang telah diinvestasikan (Munawir, 2015).dengan tujuan suatu perusahaan yaitu mensejahterakan pemiliki perusahan dan meningkatkan nilai suatu perusahaan.

Kinerja perusahaan dapat diartikan sebagai prestasi yang dicapai perusahaan dalam suatu periode yang mencerminkan tingkat kesehatan perusahaan. Untuk mencapai suatu kinerja yang baik dapat dibuktikan bagaimana perusahaan dapat menghasilkan keuntungan sebanyakbanyaknya yang akan menjadi daya tarik bagi para investor, perusahaan akan memberikan keuntungan baginya dan akan mengurangi risiko. Kinerja yangbaik bukanlah suatu yang mudah bagi perusahaan. Banyak penelitian yang dilakukan oleh peneliti dalam menentukan faktor-faktor yang dapat mempengaruhi kinerja perusahaan salah satunya yaitu tata kelola perusahaan yang baik atau Good Corporate Governance (GCG).

Forum for Corporate Governance In Indonesia (FCGI),merumuskan Good Corporate Governance (GCG) merupakan bentuk pengelolaan perusahaan yang baik, terhadap kepentingan para pemegang saham (publik) sebagai pemilik perusahaan dan kreditur sebagai penyandang dana ekstrem.Sistem Corporate Governance yang baik akan memberikan perlindungan efektif kepada para pemegang saham dan kreditur untuk memperoleh kembali atas investasi dengan wajar, tepat dan efesien, memastikan manajemen bertindak baik yang dapat dilakukan untuk kepentingan perusahaan. Dapat didefinisikan seperangkat peraturan yang mengatur hubungan antara pemegang saham, pengelola perusahaan, pihak kreditur, pemerintah, karyawan dan dan pihak - pihak yang berkepentingan lainnya baik intern maupun ekstern. Tujuannya untuk menciptakan nilai tambah bagi semua pihak yang berkepentingan atau stakeholder.

Dalam teori keagenan (agency theory), hubungan agensi muncul ketika satu orang atau lebih (principal) memperkerjakan orang lain (agent) untuk dapat memberikan suatu jasa dan kemudian mendeglagasikan wewenang untuk pengambilan keputusan kepada agent tersebut. Seorang manajer sebagai pengelola perusahaan lebih banyak mengetahui informasi tentang keadaan perusahaan tersebut dibandingkan dengan pemiliknya (pemegang saham). Oleh karena itu pengelola, manajer berkewajiban memberikan informasi perusahaan terhadap pemilik perusahaan. Akan tetapi informasi yang disampaikan tersebut terkadang tidak sesuai dengan keadaan yang sebenarnya.

Permasalahan agensi tersebut dapat memicu terjadinya biaya keagenan. Biaya keagenan dapat ditekan dengan adanya struktur kepemilikan dalam perusahaan yaitu struktur kepemilikan manajerial dan kepemilikan instusional. Kepemilikan manajerial merupakan kepemilikan saham atau dengan kata lain manajer juga sebagai pemegang saham. Pemberian kesempatan manajer untuk terlibat dalam kepemilikan saham bertujuan untuk menyetarakan kepentingan manajer dengan pemegang saham. Keterlibatan tersebut akan mendorong manajer untuk bertindak dengan hati-hati karena manajer akan turut menanggung konsekuensi atas keputusan. Manajer akan termotivasi untuk meningkatkan kinerjanya dalam mengelola perusahaan. Kepemilikan manajerial akan diukur dengan proporsi saham perusahaan yang kemudian dinyatakan dalam presentase. Selain kepemilikan manajerial, 
ISSN : $2406-7415$

E-ISSN : 2655 - 9919

JURNAL AKUNTANSI DAN BISNIS KRISNADWIPAYANA

DOI: http://dx.doi.org/10.35137/jabk.v8i1.505

kepemilikan instusional merupakan kepemilikan saham yang dimiliki oleh pihak luar baik dalam bentuk instiusi, lembaga, perusahaan, asuransi, bank atau kelompok lainnya. Kepemilikan institusional juga dianggap dapat memonitor kinerja manajemen.

Selain struktur kepemilikan yang mempengaruhi pengambilan keputusan manajer, ukuran perusahaan juga dapat mempengaruhi keputusan manajemen dan akan berakibat pada kinerja keuangan. Ukuran perusahaan adalah besar kecilnya suatu perusahaan yang dilihat dari besarnya aset yang dimiliki oleh perusahaan. Besar kecilnya perusahaan akanmempengaruhi kemampuan dalam menanggung resiko yang akan dihadapi oleh perusahaan. Perusahaan yang besar memiliki peran sebagai pemegang kepentingan yang luas. Selain itu perusahaan-perusahaan besar memiliki sumber daya untuk meningkatkan nilai perusahaan karena memiliki akses yang lebih baik dari sumber-sumber 5 informasi eksternal dengan perusahaan kecil. Selain itu perusahaan yang besar dapat memberikan informasi yang baik untuk kepentingan investor, karena akan lebih diperhatikan oleh masyarakat yang artinya semakin mudahdan mlebih hati-hati untuk mendapatkan informasi yang akan meningkatkan nilai perusahaan

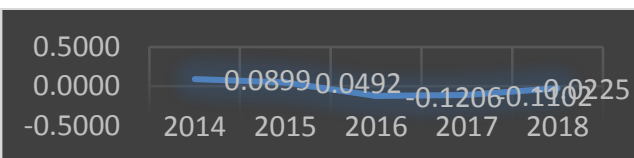

Gambar 1 Kinerja Keuangan pada perusahaan keuangan yang terdaftar di Bursa Efek Indonesia tahun 2014 sampai dengan tahun 2018
Volume 8 Nomor 1 (Januari - April) 2021

Dari gambar diatas terlihat perkembangan perhitungan Return On Asset (ROA) dari tahun 2014 sampai dengan tahun 2018 mengalami penurunan. Fenomena tentang pengukuran Return On Asset (ROA) yang terjadi salah satunya pada Bank Rakyat Indonesi (Perseroan) Tbk, dimana dari tahun 2014 sampai dengan tahun 2018 secara berturut - turut mengalami mengalami penurunan.

\section{Tabel 1 Kinerja Keuangan pada Perusahaan Keuangan Selama Tahun 2014 sampai 2018}

\begin{tabular}{|c|c|c|}
\hline Tahun & $\begin{array}{c}\text { Return On Asset } \\
\text { (ROA) }\end{array}$ & Keterangan \\
\hline 2014 & 0,0899 & ROA Turun \\
\hline 2015 & 0,0492 & ROA Turun \\
\hline 2016 & $-0,1206$ & ROA Turun \\
\hline 2017 & $-0,1102$ & ROA Naik \\
\hline 2018 & $-0,0225$ & ROA Naik \\
\hline
\end{tabular}

Pada tahun 2014 tingkat Return On Asset (ROA) Bank Rakyat Indonesi (Perseroan) Tbk adalah 0,0309, 0,0289 tahun 2015, 0,0261 tahun 2016, 0,0258 tahun 2017, dan pada tahun 2018 sebesar 0,0025 . Sehingga dapat dilihat bahwa nilai laba bersih perusahaan selama penelitian ini cenderung mengalami penurunan dan mengakibatkan nilai Return On Asset (ROA) perusahaan menurun, Tururnya nilai Return On Asset (ROA) dari tahun ke tahun menunjukkan bahwa kemampuan perusahaan untuk menghasilkan laba bersih maksimal dengan menggunakan aktivinya secara produktif semakin menurun dengan demikian keuntungan yang diperoleh perusahaan berdasarkan investasi yang ditanamkan pada perusahaan tersebut dalam 
ISSN : $2406-7415$

E-ISSN : 2655 - 9919

JURNAL AKUNTANSI DAN BISNIS KRISNADWIPAYANA

DOI: http://dx.doi.org/10.35137/jabk.v8i1.505

Volume 8 Nomor 1 (Januari - April) 2021

kondisi rentabilitas ekonomis yang kurang baik.

Gita Andriani Tisna (2016) dalam penelitiannya menghasilkan bahwaGood Corporate Governance (GCG) dan ukuran perusahaan berpengaruh secara parsial dan simultan terhadap kinerja keuangan perusahaan, penelitian yang dilakukan Ryan Anugrah Pratiwi (2017) secara simultantidak menunjukkan pengaruh yang signifikan dari variabel Good Corporate Governance (GCG) dan ukuran perusahaan terhadapnilai perusahaan makanan dan minuman yang terdaftar di Bursa Efek Indonesia (BEI).

Sedangkan Ayu Permata Kasih (2016) menunjukkan bahwa pertama dewan direksi tidak berpengaruh signifikan terhadap kinerja keuangan perusahaan, kedua dewan komisaris tidak berpengaruh signifikan terhadap kinerja keuangan perusahaan, ketiga kepemilikan manajerial berpengaruh signifikan terhadap kinerja keuangan perusahaan, keempat ukuran perusahaan tidak berpengaruh signifikan terhadap kinerja keuangan perusahaan sehingga berdasarkan hasil uji $\mathrm{F}$ diperoleh Good Corporate Governance (GCG) dan ukuran perusahaan secara bersama-sama berpengaruh terhadap kinerja perusahaan.

Berdasarkan hal-hal yang melatar belakangi masalah tersebut diatas penulis tertarik untuk melakukan untuk menganalisis pengaruh Good Corporate Governance Dan Ukuran Perusahaan Terhadap Kinerja Keuangan Perusahaan Pada Perusahaan Keuangan Yang Terdaftar Di Bursa Efek Indonesia Tahun 2014 Sampai Dengan Tahun 2018.

\section{LANDASAN TEORI}

\section{Ukuran Perusahaan}

Harahap (2015 :23) menjelaskan bahwa pengukuran ukuran perusahaan diukur dengan logaritma natural (Ln) dari rata-rata total aktiva (total asset) perusahaan. Penggunaan total aktiva berdasarkan pertimbangan bahwa total aktiva mencerminkan ukuran perusahaan dan diduga mempengaruhi ketepatan waktu.

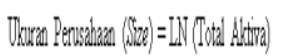

Keterangan :

LN = Logaritma Natural.

\section{Good Corporate Governance}

Damanyanti (2016) menjelaskan Good corporate governance adalah sebuah konsep yang menekankan pentingnya hak pemegang saham untuk memperoleh informasi yang akurat, benar dan tepat waktu. Selain itu juga menunjukkan kewajiban perusahaan untuk mengungkapkan (disclosure) semua informasi keuangan kinerja perusahaan secara akurat, tepat waktu dan transparan.

Pengelolaan perusahaan (corporate governance) itu sendiri dapat diartikan secara luas pada literatur yang ada dan terbatas. Secara terbatas, istilah tersebut berkaitan dengan hubungan antara manajer, direktur, auditor dan pemegang saham, sedangkan secara luas istilah pengelolaan perusahaan dapat meliputi kombinasi hukum, peraturan, aturan pendaftaran dan praktik pribadi yang meningkatkan perusahaan menarik modal masuk, memiliki kinerja yang efesien, menghasilkan keuntungan, serta memenuhi harapan masyarakat secara umum dan sekaligus 
ISSN : $2406-7415$

E-ISSN : 2655 - 9919

JURNAL AKUNTANSI DAN BISNIS KRISNADWIPAYANA

DOI: http://dx.doi.org/10.35137/jabk.v8i1.505

kewajiban hukum. Keberadaan organ-organ tambahan tersebut memiliki fungsi dan tanggung jawab yang berkaitan dengan pelaksanaan Good Corporate Governance. Organ tambahan untuk melengkapi penerapan Good Corporate Governance (Agoes, 2016:109), yaitu :
a. Ukuran Dewan Komisaris
b. Dewan Komisaris Independen
c. Kepemilikan Institusional
d. Kepemilikan Manajerial
e. Komite Audit

\section{Kinerja Keuangan}

Untuk memutuskan suatu badan usaha atau perusahaan memiliki kualitas yang baik maka ada dua penilaian yang paling dominan yang dapat dijadikan acuan untuk melihat badan usaha atau perusahaan tersebut telah menjalankan suatu kaidahkaidah manajemen yang baik. Penilaian ini dapat dilakukan dengan melihat sisi kinerja keuangan (financial performance) dan kinerja non keuangan (non financial performance). Kinerja keuangan melihat pada laporan keuangan yang dimiliki oleh perusahaan atau badan usaha yang bersangkutan dan itu tercermin dari informasi yang diperoleh pada neraca, laporan laba rugi, laporan perubahan ekuitas dan laporan arus kas serta hal-hal lain yang turut mendukung sebagai penguat penilaian financial performance tersebut.

Fahmi (2015:2) berpendapat bahwa kinerja keuangan adalah adalah suatu analisis yang dilakukan untuk melihat sejauh mana suatu perusahaan telah melaksanakan dengan menggunakan aturan-aturan pelaksanaan keuangan secara baik dan benar. Untuk menilai atau mengukur kinerja keuangan perusahaan menggunakan rasio
Volume 8 Nomor 1 (Januari - April) 2021

keuangan untuk mengetahui apakah perusahaan mencapai target seperti yang telah diharapkan atau tidak. Kemudian juga dapat menilai kemampuan manajemen dalam memberdayakan sumber daya perusahaan secara efektif.Analisis rasio keuangan dapat dikelompokan menjadi 6jenis , yaitu: (Fahmi, 2015:16)

a. Rasio Likuiditas, rasio ini menyatakan kemampuan perusahaan untuk memenuhi kewajibannya dalam jangka pendek secara tepat waktu. Rasio likuiditas terdiri dari :current ratio, quick ratio, dan net working capital

b. Rasio Leverage rasio ini mengukur seberapa besar perusahaan dibiayai oleh hutang. Rasio solvabilitas terdiri dari:debt to total assets, debt to equity ratio, times interest earned, fixed change coverage, dan cash flow coverage.

c. Rasio Aktivitas rasio ini menunjukan kemampuan perusahaan dalam memanfaatkan harta yang dimilikinya untu menunjang aktivitas perusahaan. Rasio Aktivitas terdiri dari:total asset turnover, fixed asset turnover, account receivable turnover, dan inventory turnover.

d. Rasio Profitabilitas rasio ini menunjukan kemampuan dari perusahaan dalam menghasilkan keuntungan atau investasi. Rasio Profitabilitasterdiri dari :gross profit margin, net profit margin, return on asset, return on equity, dan operating ratio.

e. Rasio pertumbuhan rasio ini mengukur seberapa besar kemampuan perusahaan dalam mempertahankan posisinya di dalam industri dan dalam perkembangan ekonomi secara umum. Rasio pertumbuhan dilihat dari :sales, earning after tax, laba perlembar saham, dividen 
ISSN : $2406-7415$

E-ISSN : 2655 - 9919

JURNAL AKUNTANSI DAN BISNIS KRISNADWIPAYANA

DOI: http://dx.doi.org/10.35137/jabk.v8i1.505

perembar saham, dan harga pasar per lembar saham.

f. Ratio Pasar rasio ini menggambarkan kondisi yang terjadi di pasar. Rasio pasar terdiri dari: dividend yield, dividend payout ratio, price earning ratio, earning per share, dan book value per share

$g$.

\section{Kerangka Konseptual}

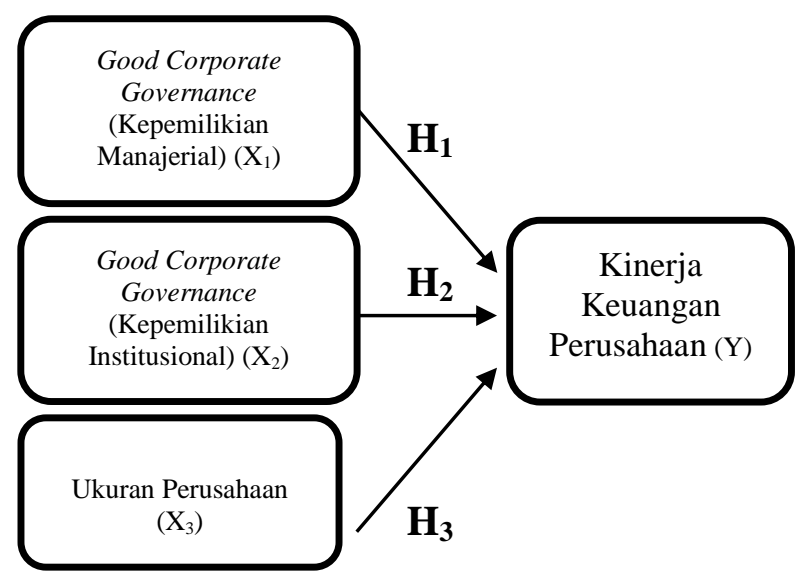

Gambar 2 Kerangka Konseptual

\section{Pengembangan Hipotesis}

\section{Pengaruh Kepemilikan Manajerial terhadap Kinerja Keuangan Perusahaan}

Kepemilikan saham oleh manajemen akan menurunkan permasalahan agensi karena semakin banyak saham yang dimiliki oleh manajemen maka akan memperkuat motivasi manajemen dalam bekerja sehingga meningkatkan nilai saham perusahaan di masa yang akan datang. Nilai saham menggambarkan nilai yang diberikan para investor terhadap perusahaan. Perusahaan dengan nilai saham tinggi berarti nilai perusahaan tersebut baik dimata para calon investor
Volume 8 Nomor 1 (Januari - April) 2021

sehingga permintaan akan sahamnya juga tinggi. Nilai perusahaan tersebut akan meningkat seiring dengan kinerja perusahaan yang semakin meningkat pula. Rizka Khairuni (2019) menyebutkan struktur kepemilikan manajerial merupakan salah satu mekanisme dalam corporate governance karena dengan kepemilikan manajerial dapat menurunkan conflict of interest yang disebabkan oleh perbedaan kepentingan antara pemilik dan manajer. Semakin besar kepemilikan saham oleh manajemen dalam perusahaan maka semakin produktif tindakan manajer dalam meningkatkan kinerja perusahaan.

$\mathrm{H}_{1}$ : Kepemilikan manajerial berpengaruh terhadap kinerja keuangan perusahaan

\section{Pengaruh Kepemilikan Institusional terhadap Kinerja Keuangan Perusahaan}

Rizka Khairuni (2019) menjelaskan bahwa kepemilikan institusional adalah saham perusahaan yang dimiliki oleh institusi atau lembaga yaitu perusahaan asuransi, bank, perusahaan investasi, dan kepemilikan institusi lain. Dengan adanya investor institusional, akan meminimalisir penyelewengan yang mungkin dilakukan oleh manajer karena pengawasan terhadap kinerja keuangan serta keterlibatan dalam pengambilan keputusan oleh investor institusional. Semakin besar kepemilikan institusional maka semakin efisien pemanfaatan aset perusahaan.

$\mathrm{H}_{2}:$ Kepemilikan
berpengaruh terhadap $\begin{array}{r}\text { institusional } \\ \text { keuangan perusahaan }\end{array}$


ISSN : $2406-7415$

E-ISSN : 2655 - 9919

JURNAL AKUNTANSI DAN BISNIS KRISNADWIPAYANA

DOI: http://dx.doi.org/10.35137/jabk.v8i1.505

Volume 8 Nomor 1 (Januari - April) 2021

\section{Ukuran Perusahaan terhadap Kinerja Keuangan Perusahaan}

Ayu (2014) berpendapat bahwa ukuran perusahaan merupakan suatu skala dimana diklasifikasikannya perusahaan menurut besar kecilnya. Besar kecilnya suatu perusahaan dapat dilihat dari jumlah pendapatan, total aset, jumlah karyawan dan total modal maka akan mencerminkan keadaan perusahaan yang semakin kuat. Menurut Departemen Perindustrian dan Perdagangan Republik Indonesia ukuran perusahaan terbagi dalam tiga kategori yaitu perusahaan besar, perusahaan menengah dan perusahaan kecil. Suatu perusahaan yang sudah mapan akan memiliki aktivitas yang lebih besar dan memiliki risiko atau tanggung jawab yang besar pula sesuai dengan aktivitas yang dilakukan. Semakin besar suatu perusahaan maka akan semakin dikenal masyarakat, yang berarti semakin mudah untuk mendapatkan informasi mengenai perusahaan.

$\mathrm{H}_{3}$ : Ukuran Perusahaan berpengaruh terhadap kinerja keuangan perusahaan
Variabel bebas dalam penelitian ini diukur dengan :
a. Good
Corporate
Governance
(kepemilikan manajerial)
b. Good Corporate Governance
(kepemilikan instisional)

c. Ukuran perusahaan

Variabel terikat dalam penelitian ini adalah kinerja keuangan yang diukur menggunakan :

$$
\mathrm{ROA}=\frac{\text { Laba Bersih }}{\text { Total Aset }}
$$

(Kasmir, 2017:204)

Penelitian menggunakan jenis data sekunder, dengan informasi yang diperoleh dari pengumpulan data melalui dokumentasi dengan cara mengambil data laporan keuangan tahunan pada perusahaan keuangan di Bursa Efek Indonesia pada situs resmi www.bi.go.id pada tahun 2014 sampai dengan tahun 2018. Dengan teknik analisis data yang digunakan dalam penelitian ini adalah uji statistic deskriptif, uji asumsi klasik, analisis regresi linier berganda dan uji hipotesis

\section{METODE PENELITIAN}

Dalam penelitian ini objek penelitiannya adalah kinerja keuangan, sedangkan variabel bebas dari penelitian ini adalah Good Corporate Governance (kepemilikan manajerial dan kepemilikan instisional) dan ukuran perusahaan pada perusahaan keuangan yang terdaftar di Bursa Efek Indonesia tahun 2014 sampai dengan tahun 2018, yang diambil berdasarkan teknik purposive sampel.

\section{HASIL PENELITIAN DAN PEMBAHASAN Hasil Penelitian}

\section{Uji Statistik Deskriptif}

Berdasarkan tabel 2 menunjukkan bahwa $\mathrm{N}$ atau jumlah data setiap variabel yang valid berjumlah 16, dengan variabel yang digunakan adalah kinerja keuangan, kepemilikan manajeril, kepemilikan institusional, dan ukuran perusahaan. Berikut ini adalah nilai rata-rata (mean), minimum, maksimum dan standar 
ISSN : $2406-7415$

E-ISSN : 2655 - 9919

JURNAL AKUNTANSI DAN BISNIS KRISNADWIPAYANA

DOI: http://dx.doi.org/10.35137/jabk.v8i1.505

deviasi dari variabel penelitian yang digunakan :

\section{Tabel 2 Hasil Uji Statistik Deskriptif}

\begin{tabular}{|lr|r|r|r|r|}
\hline & $\mathrm{N}$ & \multicolumn{1}{|c|}{ Minimum } & \multicolumn{1}{|c|}{ Maximum } & \multicolumn{1}{c|}{ Mean } & $\begin{array}{c}\text { Std. } \\
\text { Deviation }\end{array}$ \\
\hline Y (KK) & 16 & -73.00 & 431.00 & 158.43 & 159.17 \\
\hline X1 (KM) & 16 & 132.00 & 818018.00 & 129448.81 & 260162.01 \\
\hline X2 (KI) & 16 & 32.00 & 4411031.00 & 1076059.81 & 1826295.73 \\
\hline X3 (UP) & 16 & 183627.00 & 300411.00 & 247427.00 & 45534.29 \\
\hline $\begin{array}{l}\text { Valid N } \\
\text { (listwise) }\end{array}$ & 16 & & & & \\
\hline
\end{tabular}

a. Kinerja keuangan memiliki nilai minimum sebesar -73.00 nilai maksimum sebesar 431.00 dari periode 2014-2018 diketahui nilai mean sebesar 158.4375 serta nilai standar deviasi sebesar 159.17159 yang artinya nilai mean lebih kecil dari nilai standar sehingga penyimpangan data yang terjadi tingggi maka penyebaran nilainya tidak merata.

b. Kepemilikan manajerial memiliki nilai minimum sebesar 132.00, nilai maksimum sebesar 818018.00, dari periode 2016-2018 diketahui nilai mean sebesar 129448.8125, serta nilai standar deviasi sebesar 260162.01520 yang artinya nilai mean lebih kecil dari nilai standar sehingga penyimpangan data yang terjadi tinggi maka penyebaran nilainya tidak merata.

c. Kepemilikan institusional memiliki nilai minimum sebesar 32.00, nilai maksimum sebesar 4411031.00, dari periode 2016-2018 diketahui nilai mean sebesar 1076059.8125, serta nilai standar deviasi sebesar 1826295.73807 yang artinya nilai mean lebih kecil dari nilai standar sehingga penyimpangan
Volume 8 Nomor 1 (Januari - April) 2021

data yang terjadi tinggi maka penyebaran nilainya tidak merata.

d. Ukuran perusahaan memiliki nilai minimum sebesar 183627.00, nilai maksimum sebesar 300411.00, dari periode 2016-2018 diketahui nilai mean sebesar 247427.0000, serta nilai standar deviasi sebesar 45534.29140 yang artinya nilai mean lebih besar dari nilai standar sehingga penyimpangan data yang terjadi rendah maka penyebaran nilainya merata.

\section{Uji Asumsi Klasik}

Berdasarkan uji normalitas menggunakan Uji Kolmogrov-Smirnov (S-K) pada tabel 3 dibawah diperoleh hasil nilai Asymp. Sig (2-tailed) sebesar 0,200 sehingga nilai tersebut berada diatas tingkat signifikan 0,05 yang menjelaskan bahwa penyebaran residual data berdistribusi normal.

\section{Tabel 3 Hasil Uji Normalitas} Menggunakan KS

\begin{tabular}{|c|c|c|}
\hline One-Sample Ko & logorov-Sn & $\begin{array}{l}\text { Unnov Test } \\
\text { Unstandardized } \\
\text { Residual }\end{array}$ \\
\hline \multicolumn{2}{|l|}{$\overline{\mathrm{N}}$} & 16 \\
\hline \multirow[t]{2}{*}{ Normal Parameters ${ }^{\mathrm{a}, \mathrm{b}}$} & Mean & .0000000 \\
\hline & $\begin{array}{l}\text { Std. } \\
\text { Deviation }\end{array}$ & 110.65060215 \\
\hline \multirow{3}{*}{$\begin{array}{l}\text { Most Extreme } \\
\text { Differences }\end{array}$} & Absolute & .127 \\
\hline & Posit & .127 \\
\hline & ve & -.126 \\
\hline \multicolumn{2}{|l|}{ Test Statistic } & .127 \\
\hline \multicolumn{2}{|l|}{ Asymp. Sig. (2-tailed) } & $.200^{\mathrm{c}, \mathrm{d}}$ \\
\hline \multicolumn{3}{|c|}{$\begin{array}{l}\text { a. Test distribution is Normal. } \\
\text { b. Calculated from data. } \\
\text { c. Lilliefors Significance Correction. } \\
\text { d. This is a lower bound of the true significance. }\end{array}$} \\
\hline
\end{tabular}


ISSN : $2406-7415$

E-ISSN : 2655 - 9919

JURNAL AKUNTANSI DAN BISNIS KRISNADWIPAYANA

DOI: http://dx.doi.org/10.35137/jabk.v8i1.505

Volume 8 Nomor 1 (Januari - April) 2021

Tabel 4. Hasil Uji Autokorelasi Menggunakan DW

\begin{tabular}{|c|c|c|c|c|c|}
\hline \multicolumn{6}{|c|}{ Model Summary } \\
\hline $\begin{array}{l}\text { Mo } \\
\text { del }\end{array}$ & $\mathrm{R}$ & $\begin{array}{c}\mathrm{R} \\
\text { Square }\end{array}$ & $\begin{array}{l}\text { Adjusted } \\
\text { R Square }\end{array}$ & $\begin{array}{c}\text { Std. } \\
\text { Error of } \\
\text { the } \\
\text { Estimate }\end{array}$ & $\begin{array}{l}\text { Durbin- } \\
\text { Watson }\end{array}$ \\
\hline 1 & $.508^{\mathrm{a}}$ & .258 & .198 & 2.19600 & 2.108 \\
\hline
\end{tabular}

Berdasarkan hasil output SPSS pada tabel 4 menunjukkan bahwa nilai uji autokorelasi nilai DW sebesar 2.018, dimana nilai du pada tabel DurbinWatson dengan $\mathrm{n}$ yang menunjukkan sampel 16, dan $\mathrm{k}$ yang menunjukkan jumlah variabel bebas sebanyak 3 adalah 0.857 untuk dL dan 1.728 untuk dU. Sehingga nilai DW yang didapat dari uji tersebut tergolong pada jarak $\mathrm{dU}<\mathrm{d}<4$ $\mathrm{dU}$, dengan nilai dU tabel sebesar $1.728<$ $2.018<2.272$ menunjukkan bahwa model yang digunakan terbebas dari autokorelasi.

Tabel 5 Hasil Uji Multikolinearitas

\begin{tabular}{|l|l|r|r|l|}
\hline No. & Variabel & Tolerance & VIF & Keputusan \\
\hline 1 & KM & .738 & 1.355 & $\begin{array}{l}\text { Tidak terdapat } \\
\text { multikolinearitas }\end{array}$ \\
\hline 2 & KI & .364 & 2.748 & $\begin{array}{l}\text { Tidak terdapat } \\
\text { multikolinearitas }\end{array}$ \\
\hline 3 & UP & .304 & 3.292 & $\begin{array}{l}\text { Tidak terdapat } \\
\text { multikolinearitas }\end{array}$ \\
\hline
\end{tabular}

Berdasarkan tabel 5 diatas tersebut, terlihat bahwa hasil perhitungan tolerance variabel independen lebih dari 0,10 yang berarti tidak ada korelasi antara variabel independen. Dan hasil valance inflation faktor (VIF) pada uji multikolonieritas tersebut menunjukkan bahwa setiap variabel independen memiliki nilai VIF dibawah 10. Jadi dari penjelasan tersebut dapat disimpulkan bahwa tidak ada multikolonieritas antara variabel independen dalam model regresi

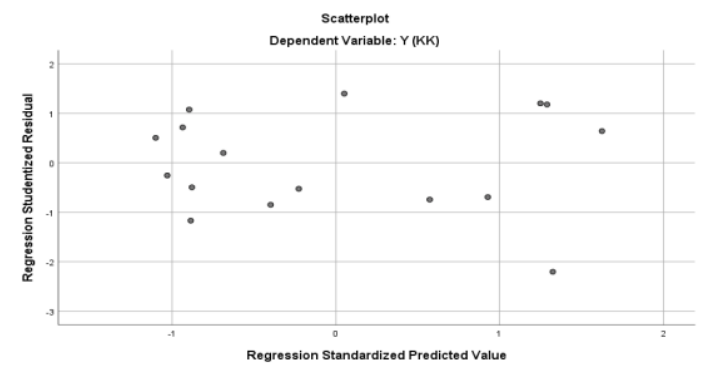

\section{Gambar 3 Uji Heteroskedastisitas Menggunakan Grafik Plot}

Dari grafik scatterplots pada kinerja keuangan diatas terlihat bahwa titik titik menyebar secara acak serta tersebar diatas dan dibawah angak 0 pada sumbu Y sehingga dapat disimpulkan bahwa tidak ada terjadi heteroskedastisitas.
3. Analisis Regresi Linier Berganda Tabel 6 Hasil Uji Regresi Linier Berganda

\begin{tabular}{|c|c|c|c|}
\hline \multirow[b]{2}{*}{ Model } & \multicolumn{2}{|c|}{$\begin{array}{l}\text { Unstandardized } \\
\text { Coefficients }\end{array}$} & \multirow{2}{*}{$\begin{array}{c}\text { Standardized } \\
\text { Coefficients } \\
\text { Beta }\end{array}$} \\
\hline & B & Std. Error & \\
\hline $1 \quad$ (Constant) & 1197.1 & 333.807 & \\
\hline X1 (KM) & .000 & .000 & .501 \\
\hline X2 (KI) & -9.171 & .000 & -1.052 \\
\hline X3 (UP) & -.004 & .001 & -1.133 \\
\hline
\end{tabular}

Dari hasil uji regresi berganda tabel 6 terbentuklah persamaan regresi linier berganda sebagai berikut :

$$
\begin{aligned}
\mathrm{KK}= & 1197.1+0.000 \mathrm{KM}-9.171 \mathrm{KI}- \\
& 0.004 \mathrm{UP}+\mathrm{e}
\end{aligned}
$$

Penjelasan dari persamaan regresi tersebut adalah :

a. Nilai konstanta (a) adalah 1197.1

b. Arah Hubungan 
ISSN : $2406-7415$

E-ISSN : 2655 - 9919

JURNAL AKUNTANSI DAN BISNIS KRISNADWIPAYANA

DOI: http://dx.doi.org/10.35137/jabk.v8i1.505

1. Kepemilikan manajerial $\left(\mathrm{X}_{1}\right)$ mempunyai koefisien regresi dengan arah positif sebesar 0.000

2. Kepemilikan institusional $\left(\mathrm{X}_{2}\right)$ mempunyai koefisien regresi dengan arah negatif 9.171 yang berarti setiap kenaikan variabel $\mathrm{X}_{2}$ maka akan mengalami penuruna sebear 9.171, sebaliknya jika $\mathrm{X}_{2}$ mengalami penurunan maka akan mengalami kenaikan sebesar 9.171.

3. Ukuran perusahaan $\left(\mathrm{X}_{3}\right)$ mempunyai koefisien regresi dengan arah negatif 0.004 yang berarti setiap kenaikan variabel $\mathrm{X}_{2}$ maka akan mengalami penuruna sebear 0.004 , sebaliknya jika $\mathrm{X}_{2}$ mengalami penurunan maka akan mengalami kenaikan sebesar 0.004 .

\section{Uji Hipotesis}

\section{Uji Parsial (Uji t)}

Tabel 7 Hasil Uji Parsial (Uji t)

\begin{tabular}{|ll|r|r|}
\hline \multicolumn{2}{|l}{ Model } & \multicolumn{1}{l|}{ T } & \multicolumn{1}{c|}{ Sig. } \\
\hline 1 & (Constant) & 3.586 & .004 \\
\cline { 2 - 4 } & $\mathrm{X} 1(\mathrm{KM})$ & 2.143 & .053 \\
\cline { 2 - 4 } & $\mathrm{X} 2(\mathrm{KI})$ & -3.163 & .008 \\
\cline { 2 - 4 } & $\mathrm{X} 3(\mathrm{UP})$ & -3.111 & .009 \\
\hline
\end{tabular}

Berdasarkan hasil perhitungan pada tabel diatas dapat dijelaskan sebagai berikut:

1. Pengujian hipotesis pertama $\left(\mathrm{H}_{1}\right)$ $\mathrm{H}_{1}$ menyatakan bahwa kepemilikan manajerial tidak berpengaruh signifikan terhadap kinerja keuangan. Berdasarkan parameter statistic bahwa nilai $t_{\text {hitung }}$ sebesar $2.143<$ $2.201 \quad\left(\mathrm{t}_{\text {tabel }}\right)$. Pada signifikasi 5\% $(0,05)$ artinya bahwa derajat keyakinannya hanya $95 \%$ berarti
Volume 8 Nomor 1 (Januari - April) 2021

kesalahannya hanya 5\%, maka dikatakan bahwa kepemilikan manajerial tidak berpengaruh terhadap kinerja keuangan

2. Pengujian hipotesis kedua $\left(\mathrm{H}_{2}\right)$

$\mathrm{H}_{2}$ menyatakan bahwa kepemilikan institusional berpengaruh signifikan terhadap kinerja keuangan. Berdasarkan parameter statistic bahwa nilai $t_{\text {hitung }}$ sebesar -3.163> 2.201 ( $\left.\mathrm{t}_{\text {tabel }}\right)$. Pada signifikasi 5\% $(0,05)$ artinya bahwa derajat keyakinannya hanya $95 \%$ berarti kesalahannya hanya 5\%, maka dikatakan bahwa kepemilikan institusional berpengaruh negatif dan signifikan terhadap kinerja keuangan

3. Pengujian hipotesis ketiga $\left(\mathrm{H}_{3}\right)$

$\mathrm{H}_{3}$ menyatakan bahwa ukuran perusahaan berpengaruh signifikan terhadap kinerja keuangan. Berdasarkan parameter statistic bahwa nilai thitung sebesar $-3.111>$ 2.201 ( $\left.\mathrm{t}_{\text {tabel }}\right)$. Pada signifikasi 5\% $(0,05)$ artinya bahwa derajat keyakinannya hanya $95 \%$ berarti kesalahannya hanya 5\%, maka dikatakan bahwa ukuran perusahaan berpengaruh negatif dan signifikan terhadap kinerja keuangan

Uji Koefisien Determinasi $\left(\mathbf{R}^{2}\right)$ Tabel 8 Hasil Uji Koefisien Determinasi $\left(\mathbf{R}^{2}\right)$

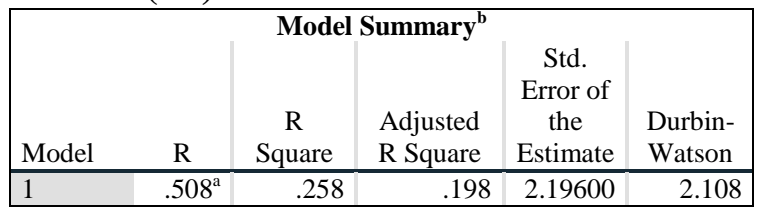

Dari tabel diatas terlihat bahwa nilai $\mathrm{R}^{2}$ dari penelitian ini adalah 0.517 , nilai tersebut memberikan arti bahwa total 
ISSN : $2406-7415$

E-ISSN : 2655 - 9919

JURNAL AKUNTANSI DAN BISNIS KRISNADWIPAYANA

DOI: http://dx.doi.org/10.35137/jabk.v8i1.505

variansi transaksi pihak berelasi disekitar rata - rata $51,7 \%$ dapat dijelaskan melalui hubungan antara kepemilikan manajerial, kepemilikan instutusional, dan ukuran perusahaan secara bersama - sama. Sedangkan sisanya 48,3\% dipengaruhi oleh faktor lain yang tidak dijelaskan.

\section{Pembahasan}

\section{Pengaruh Kepemilikan Manajerial Terhadap Kinerja Keuangan}

Berdasarkan penelitian diatas menunjukkan bahwa kepemilikan manajerial tidak berpengaruh terhadap kinerja keuangan. Dengan dibuktikan dari probabilitas signifikan kepemilikan manajerial lebih besar dari nilai nilai signifikan 0.05. Sehingga semakin tinggi kepemilikan manajerial, tidak menunjukkan kinerja keuangan pada perusahaan akan semakin baik. Hasil pengujian ini sesuai dengan konsistensasi penelitian yang dilakukan oleh Rizka Khairuni (2019) yang menunjukkan kepemilikan manajerial (KM) memiliki nilai koefisien regresi signifikansilebih besar dari tingkat signifikansi 0,05 yang menunjukkan bahwa kepemilikan manajerial tidak memiliki pengaruh terhadap kinerja keuangan.

2. Pengaruh Kepemilikan Institusional Terhadap Kinerja Keuangan

Kepemilikan institusional tidak berpengaruh negative terhadap kinerja keuangan karena pada signifikan yang lebih kecil dari nilai signifikan 0.05. menunjukkan bahwa kepemilikan institusional berpengaruh terhadap kinerja keuangan. Semakin besar kepemilikan institusional maka semakin efisien pemanfaatan aset perusahaan dan
Volume 8 Nomor 1 (Januari - April) 2021

pengelolaan kinerja keuangan. Hasil penelitian tersebut mendukung penelitian yang dilakukan oleh Melia Agustina (2015) menunjukkanbahwa kepemilikan institusional dan ukuran perusahaan berpengaruh secara negatif dan signifikan terhadap kinerja keuangan.

\section{Pengaruh Ukuran Perusahaan} Terhadap Kinerja Keuangan

Ukuran perusahaan berpengaruh terhadap kinerja keuangan karena pada signifikan sebesarlebih kecil dari nilai signifikan 0.05. memiliki persamaan dengan yang dilakukan oleh Melia (2015) yang menyatakan bahwa ukuran perusahaan berdampak negatif signifikan terhadap ROA. Hal tersebut berarti semakin besar ukuran perusahaan, maka ROA menjadi rendah (turun). ini terjadi karena diduga bahwa sektor keuangan yang sebagian besar terdiri atas sub sektor bank (proporsi Bank 53,45\%, lembaga pembiayaan $20,69 \%$, perusahaan efek $12,07 \%$, asuransi $13,79 \%$ ), menggunakan asetnya untuk melakukan ekspansi yaitu dengan membuka kantor-kantor cabang baru sehingga ROA yang dihasilkan menjadi tidak begitu tinggi. Hal tersebut dapat dilihat pada laporan perekonomian Indonesia tahun 2013 yang menyebutkan bahwa dari tahun 2011-2013 terdapat jumlah kantor cabang yang selalu meningkat (2011 kisaran 12.000, 2012 kisaran 14.000, dan 2013 kisaran 16.000). Peningkatan kantor cabang tersebut guna untuk mendukung peningkatan akses masyarakat .terhadap sistem keuangan. 
ISSN : $2406-7415$

E-ISSN : 2655 - 9919

JURNAL AKUNTANSI DAN BISNIS KRISNADWIPAYANA

DOI: http://dx.doi.org/10.35137/jabk.v8i1.505

Volume 8 Nomor 1 (Januari - April) 2021

\section{KESIMPULAN DAN SARAN}

\section{Kesimpulan}

Berdasarkan hasil penelitian dapat disimpulkan bahwa :

1. Kepemilikan manajerial tidak berpengaruh terhadap kinerja keuangan, berdasarkan parameter statistic bahwa nilai $\mathrm{t}_{\text {hitung }}$ sebesar $2.143>2.201\left(\mathrm{t}_{\text {tabel }}\right)$. Pada signifikasi $5 \% \quad(0,05)$ artinya bahwa derajat keyakinannya hanya $95 \%$ berarti kesalahannya hanya $5 \%$, maka dikatakan bahwa kepemilikan manajerial tidak berpengaruh terhadap kinerja keuangan. Sehingga pada uji hipotesis ini tidak membuktikan bahwa semakin tinggi kepemilikan manajerial maka kinerja keuangan pada perusahaan akan semakin baik.

2. Kepemilikan institusional berpengaruh terhadap kinerja keuangan, berdasarkan parameter statistic bahwa nilai $t_{\text {hitung }}$ sebesar $-3.163>-1.746 \quad\left(\mathrm{t}_{\text {tabel }}\right)$. Pada signifikasi 5\% $(0,05)$ artinya bahwa derajat keyakinannya hanya $95 \%$ berarti kesalahannya hanya 5\%, maka dikatakan bahwa kepemilikan institusional berpengaruh negatif dan signifikan terhadap kinerja keuangan. Semakin besar kepemilikan institusional maka semakin efisien pemanfaatan aset perusahaan dan pengelolaan kinerja keuangan

3. Ukuran perusahaan berpengaruh signfikan terhadap kinerja keuangan, berdasarkan parameter statistic bahwa nilai $\mathrm{t}_{\text {hitung }}$ sebesar $-3.111>-1.753$ $\left(\mathrm{t}_{\text {tabel }}\right)$. Pada signifikasi 5\% $\quad(0,05)$ artinya bahwa derajat keyakinannya hanya $95 \%$ berarti kesalahannya hanya $5 \%$, maka dikatakan bahwa ukuran perusahaan berpengaruh negatif dan signifikan terhadap kinerja keuangan. Hal tersebut berarti semakin besar ukuran perusahaan, maka ROA menjadi rendah (turun).

\section{Saran}

Saran yang dapat penulis berikan kepada perusahaan, investor dan calon investor adalah sebagai berikut :

1. Untuk setiap perusahaan emiten diharapkan lebih meningkatkan lagi dalam memaksimalkan nilai suatu perusahaan, agar dapat menarik minat para investor untuk menanamkan modalnya diperusahaan.

2. Bagi investor dan calon investor yang ingin menanamkan modalnya di perusahaan Bursa Efek Indonesia diharapkan dapat lebih berhati - hati dan teliti dalam melihat kondisi perusahaan secara internal maupun eksternal perusahaan yang akan diberikan modal. Selain itu investor dan calon investor harus memperhatikan status kepemilikan saham yang ada diperusahaan tersebut.

\section{DAFTAR PUSTAKA}

Agoes, S. (2016). Auditing, Petunjuk Praktis Pemeriksaan Akuntan oleh Kantor Akuntan Publik. (E. Suharsi, Ed.) (4th ed.). Jakarta: Salemba Empat.

Fahmi, Irham. 2015. Analisis Laporan Keuangan. Bandung: Alfabeta

Gita Andriani Tisna, 2016, Pengaruh Good Corporate Governance dan Ukuran Perusahaan terhadap Kinerja 
ISSN : $2406-7415$

E-ISSN : 2655 - 9919

JURNAL AKUNTANSI DAN BISNIS KRISNADWIPAYANA

DOI: http://dx.doi.org/10.35137/jabk.v8i1.505

Volume 8 Nomor 1 (Januari - April) 2021

Keuangan Perusahaan (Pada

Perusahaan Perbankan yang

Terdaftar di Bursa Efek Indonesia

(BEI) Tahun 2010-2014), jurnal riset

akuntansi dan keuangan, 4 (2), 2016, 1035-1046.

Harahap, Sofyan Syafri. 2015. Analisis

Kritis atas Laporan Keuangan. Edisi 1-10. Jakarta: Rajawali Pers.

Kasmir. 2016. Analisis Laporan Keuangan. Jakarta: Raja Grafindo Persada

Melia Agustina Tertius, 2015, Pengaruh Good Corporate Governance terhadap Kinerja Perusahaan pada Sektor Keuangan, business accounting review vol. 3, no. 1, januari 2015: 223-232.

Rizka Khiruni, 2019, pengaruh intellectual capital dan mekanisme corporate governance terhadap kinerja keuangan pada perusahaan manufaktur yang terdaftar di bursa efek indonesia (BEI) periode 20152017, Akuntansi dan Manajemen Vol.14, No.1, 2019. ISSN 2657-1080 
ISSN : $2406-7415$

E-ISSN : 2655 - 9919

JURNAL AKUNTANSI DAN BISNIS KRISNADWIPAYANA

DOI: http://dx.doi.org/10.35137/jabk.v8i1.505

Volume 8 Nomor 1 (Januari - April) 2021

31

Copyright (c) 2021 Diana Gustinya, SE., M.Ak., Ryan Muhammad Mutawaqqil Billah

\section{c) (1)(2)}

This work is licensed under a Creative Commons Attribution-NonCommercial-ShareAlike 4.0 International License 